\title{
Analysis of motivation towards sports practice in students of Primary Education in Galicia: A descriptive study
}

\author{
MARCOS MECÍAS-CALVO ${ }^{1}$, RUBÉN NAVARRO-PATÓN² ${ }^{\Downarrow}$, PEDRO JOSUÉ NEIRA-MARTÍN ${ }^{3}$, JAVIER $^{2}$ \\ RICO-DÍAZ ${ }^{4}$ \\ ${ }^{1}$ Faculty of Health Sciences, European University of the Atlantic, Santander, Spain \\ ${ }^{2}$ Faculty of Teacher Training, University of Santiago de Compostela, Lugo, Spain \\ 3 Menéndez Pelayo Primary School, Lugo, Spain \\ ${ }^{4}$ Faculty of Education Sciences, University of Santiago de Compostela, Santiago de Compostela, Spain
}

\begin{abstract}
The current technological revolution has benefited the development of the human being. However, sedentary lifestyle has increased, and consequently, health problems, such as childhood obesity. The combination of physical activity with appropriate educational strategies are the most effective tools to fight against childhood obesity. But it is necessary to take into account the motivation towards the practice of physical exercise to generate the necessary adherence to generate healthy lifestyles and increase the effectiveness of the programs. Therefore, the objective of this study was to determine the reasons for sports practice of students in grades 5 and 6 of Primary Education according to gender and age in 4 Galician schools. 163 students between 10 and 12 years old, of which 80 were boys $(49.07 \%)$ and 83 girls $(50.07 \%)$ covered the questionnaire of the Self-Report of Motives for the Practice of Physical Exercise (AMPEF) and the results obtained showed differences statistically significant in the gender factor in weight and body image $(p=.022)$, competition $(p<.001)$, muscular strength and endurance $(p=.001)$ and health urgency $(p=.037)$. Schoolchildren show a motivation for the practice of activity influenced by weight and body image, competition, muscular strength and endurance, these motivations being greater in boys, and the urgency of health in girls.
\end{abstract}

Keywords: Motivation; Physical activity; Primary education; Health; AMPEF.

Cite this article as:

Mecías-Calvo, M., Navarro-Patón, R., Neira-Martín, P.J., \& Rico-Díaz, J. (2021). Analysis of motivation towards sports practice in students of Primary Education in Galicia. A descriptive study. Journal of Human Sport and Exercise, 16(3), 595-605. https://doi.org/10.14198/jhse.2021.163.09

Corresponding author. Facultad de Formación de Profesorado. Universidade de Santiago de Compostela. Avda. Ramón Ferreiro s/n, 27001, Lugo. Spain. https://orcid.org/0000-0003-2555-0319

E-mail: ruben.navarro.paton@usc.es

Submitted for publication January 3, 2020.

Accepted for publication March 10, 2020.

Published July 01, 2021 (in press April 24, 2020).

JOURNAL OF HUMAN SPORT \& EXERCISE ISSN 1988-5202

(c) Faculty of Education. University of Alicante.

doi:10.14198/jhse.2021.163.09 


\section{INTRODUCTION}

The technological revolution brought several benefits to the human being development. However, it interfered also in people's lifestyles making them more sedentary (Salas, 2016). This sedentary lifestyle, joined to a not healthy lifestyle, generated an increase of health problems (Campo et al., 2017), such as obesity, especially among children (Muñoz, Fernández, \& Navarro, 2015).

Overweight among children is considered one of the main public health problems worldwide (Aranceta \& Pérez, 2018; Martínez et al., 2012; Salas, 2016). Nowadays it is already known as the XXI century disease, due to the mortality because of morbidity, life quality and also the sanitary expense involved (Alba, 2016). Its origin is multifactorial and the lack of physical activity (AF) can be one of those factors(Organización Mundial de la Salud, 2018), especially among children and teenagers (Aranceta \& Pérez, 2018).

Besides the benefits that the AF has to health at all ages, it also has multiple benefits among children and teenagers such as socialization, mental processes, school performance and the improvement of quality of life for those who practice it (De Greeff, Bosker, Oosterlaan, Visscher, \& Hartman, 2018; Donnelly et al., 2016; Marques, Gómez, Martins, Catunda, \& Sarmento, 2016; Pino, Portela, \& Abalde, 2016), that is why AF can have a fundamental role to prevent overweight.

On the other hand, effective long term strategies against children's obesity are those carried out at schools, mixing AF with the teacher's recommendations about a healthy lifestyle (Martínez et al., 2012). For that matter, school's Physical Education it's one of the tools in order to fight this situation (López, Navarro, \& Basanta, 2015), generating healthy habits and practicing AF during spare time, not only during the school stage, but also along the years, as it is said on the Organic Law 8/2013, December 9th for the improvement of educative quality.

In Spain there is a highlighted decrease of the sportive practice during teenage years, that is why is necessary to know and intervene on the younger population before this decrease occurs, establishing strategies on long term healthy habits for young populations, allowing a better bond and so a lasting healthier lifestyle (Grosso \& Galvano, 2016; Sabo \& Veliz, 2016).

Given this assumptions, motivation and enjoyment, are considered main factor of the adherence to physical activity practice (Navarro-Patón, Lago-Ballesteros, Basanta-Camiño, \& Arufe-Giraldez, 2019). This is really important in order to develop strategies which promote physical activity and reduce the inactivity settled down among the Spanish population during the last few decades (Barbeira, Navarro, \& Rodriguez, 2017). This will make young people develop healthy habits and the practice of physical activity, increasing this way the possibilities of a high quality of life during their adult life (Pumar, Navarro, \& Basanta, 2015; Rios, Navarro, Arufe, \& Pérez, 2018). Accordingly, the Self-determination Theory (Deci \& Ryan, 1985) establishes a explanatory model of the human motivation, so the way people are free involved to carry out physical exercise considering psychological mechanisms of the behaviour and searching for a higher self-determinated motivation can be discovered. This is because this kind of motivation is highly related to intrinsic motivation, while non- determinated behaviours promote extrinsic motivation, characterised because of the lack of motivation. This is why on the AF field, strategies for intrinsic motivation must be developed and also its regulation (Moreno \& Martínez, 2006). Accordingly the Self-Report of Motives for the Practice of Physical Exercise (AMPEF) is a reliable and valid tool to know the motivation towards AF (Capdevila, Niñerola, \& Pintanel, 2004). However, this tool has been applied on high school students (Portela \& Domínguez, 2017), 
university students (Capdevila et al., 2007), and even on older population (Lobo, 2009), not on younger population, as the current research, on Primary Education.

The research objectives were to establish the reasons why students of $5^{\circ}$ and $6^{\circ}$ of Primary School carried out physical activities, regarding gender (boys-girls) and age (10-12 years old), in 4 Galician schools, through the AMPEF questionnaire.

\section{METHOD}

\section{Participants}

The sample's selection for this investigation was non probabilistic and of convenience, because of the geographical proximity and the participants will. A total of 163 Primary School students participated. 80 were boys (49.07\%) and 83 girls (50.93\%); 4 schools from A Coruña, Lugo, and Pontevedra. 138 of them practiced physical activity, or extracurricular sports, and 40 of them $(22.1 \%)$ did not.

\section{Tool}

The used tool was the Self-Report of Motives for the Practice of Physical Exercise (AMPEF) (Capdevila et al., 2004), which allows the identification of the intrinsic and extrinsic motivated persons. The first ones would practice exercise to feel satisfied and because of the enjoyment of the participation (for example entertainment or competition) while the second ones would practice it in order to gain an external reward (for example loss of weight, to improve their physical appearance, or to gain social recognition).

This tool is headed by the statement "I practice (or would practice) physical exercise" and 48 items established by a Likert scale from 0 to 10 (in which 0 meant "absolutely untruth for me" and 10 "absolutely truth for me").

The scale factors were: weight and body image (for example "to keep thin") entertainment and well-being (for example "because it makes me feel good") prevention and positive health (for example "to keep healthy") competition (for example "because I like to try to win when I practice physical activities") membership (for example "to spend time with my friends") muscular strength and endurance (for example "to have more strength") social recognition (for example "to show the others I am worth it") agility and flexibility (for example "to be more agile") to control stress (for example "to help myself control the tension") competition (for example "to have goals to strive for") and health urgencies (for example "because the doctor advised me to practice physical activity").

\section{Procedure}

First of all, the collaboration of the four school was requested and detailed information about the research and its objectives was given to them. Moreover, the parents of the children were asked to sign an agreement in order to allow their kids to participate. The participants were treated on behaviour of the Helsinki rules, highlighting confidentiality and anonymity of the minors.

The used tool (AMPEF, Capdevila et al., 2004) was applied during a Physical Education session by the investigators without the presence of the teacher, in order to avoid any interference in the student's answers.

An initial explanation was given about the content of the questionnaire, and all the doubts about it were answered, and it was highlighted the fact that it was not an exam and so there were no correct or incorrect answers in order to assure honest answers. 


\section{Statistical Analysis}

The descriptive values were calculated (average and standard deviation) of the variables included in the research, and also the Cronbach Alfa Coefficient (a) and the bivariate correlations through the Pearson coefficient and the Kolmogorov-Smirnov (K-S) normality test.

Later, the MANOVA of each dependent variable was studied, with two inter-factors, one of them the age (10,11 and 12 years old) and the second one the gender (boys-girls).

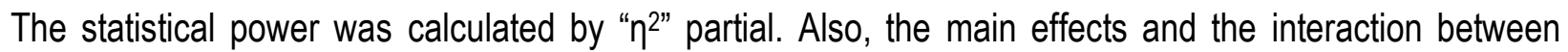
variables, using the statistical method of Bonferroni to evaluate the significance of them and to control the type I error on the later comparisons.

The analysis was made by the statistical software package for social science ((SPSS, v. 22.0 para Windows, Armonk, Nueva York), and the statistical level of significance was established on $p<.05$ with a 95\% of confidence.

\section{RESULTS}

\section{Descriptive analysis, reliability and bivariate correlations}

Table 1 shows the descriptive statistics of the used variables, the reliability analysis and its correlation.

\section{Factorial variance analysis regarding age and gender}

Table 2 shows averages and standard deviations of the AMPEF variables collected on the questionnaires regarding age, global and by gender.

The MANOVA results regarding differences associated to weight or body image showed that age is not a main factor $(p=.132)$, but gender is $\left[F(1.157)=5.335 ; p=.022, \eta^{2}=.032\right]$. Also, their interaction $[F(2,157)$ $\left.=3.388 ; p=.036, \eta^{2}=.041\right]$.

Regarding entertainment and well-being, age was not either a main factor $(p=.242)$, and neither was the gender factor $(p=.079)$ or their interaction of both $(p=.202)$. The same happens to the prevention and positive health factor, because none of them showed relevant statistical differences regarding age $(p=.562)$, gender $(p=.211)$ or their interaction $(p=.599)$.

Regarding competition, age was not a main factor $(p=.887)$, but gender was $[F(1,157)=13.979 ; p<.001$, $\left.\eta^{2}=.082\right]$. There were not relevant statistical differences regarding their interaction $(p=.090)$.

When it comes to membership, there were not observed main effects regarding age $(p=.857)$, gender $(p=$ $.340)$ or their interaction $(p=.850)$. Muscular strength and endurance did not show either a main effect of the age $(p=.702)$, but it did for the gender $\left[F(1,157)=11.812 ; p=.001, \eta^{2}=.070\right]$; There were not found relevant statistical differences on their interaction $(p=.200)$.

The social recognition factor did not show relevant statistic differences regarding age $(p=.086)$ gender $(p=$ $.127)$ or their interaction $(p=.236)$, and the same happened with the agility and flexibility [age $(p=.384)$; gender $(p=.351)$; interaction $(p=.232)$ ], the stress control [age $(p=.587)$, gender $(p=.476)$, interaction ( $p$ $=.367)$ ] and competition [age $(p=.216)$, gender $(p=.294)$, interaction $(p=.881)$ ]. 
Table 1. Mean, standard deviation, confidence analysis and bivariate correlations between the studied dimensions of the AMPEF.

\begin{tabular}{|c|c|c|c|c|c|c|c|c|c|c|c|c|c|c|}
\hline Dimensions. & $M$ & SD & $\alpha$ & 1 & 2 & 3 & 4 & 5 & 6 & 7 & 8 & 9 & 10 & 11 \\
\hline WBI (1) & 5.48 & 2.00 & .815 & 1 & $.257^{* *}$ & $.410^{* *}$ & $.369^{* *}$ & $.282^{* *}$ & $.571^{* *}$ & $.561^{* *}$ & $.413^{* *}$ & $.349^{* *}$ & $.279^{* *}$ & $.530^{* *}$ \\
\hline FWB (2) & 7.41 & 1.95 & .728 & - & 1 & $.546^{* *}$ & $.560^{* * *}$ & $.617^{\star *}$ & $.523^{* *}$ & $.189^{* * *}$ & $.330^{* *}$ & $.407^{\star *}$ & $.534^{* *}$ & $.337^{* *}$ \\
\hline PPH (3) & 7.73 & 1.89 & .836 & - & - & 1 & $.321^{* *}$ & $.403^{* *}$ & $.532^{* *}$ & .064 & $.319^{* *}$ & $.565^{* *}$ & $.400^{* *}$ & $.339^{* *}$ \\
\hline Comp. (4) & 6.11 & 2.35 & .793 & - & - & - & 1 & $.470^{* *}$ & $.502^{* *}$ & $.455^{\star *}$ & $.297^{* *}$ & $.257^{* \star}$ & $.462^{* *}$ & $.399^{* *}$ \\
\hline Affilia. (5) & 6.86 & 2.01 & .700 & - & - & - & - & 1 & $.355^{* *}$ & $.202^{* *}$ & $.214^{* *}$ & $.357^{* \star}$ & $.463^{* *}$ & $.369^{* *}$ \\
\hline EME (6) & 6.49 & 2.14 & .812 & - & - & - & - & - & 1 & $.474^{* *}$ & $.392^{* *}$ & $.528^{* *}$ & $.493^{* *}$ & $.614^{* *}$ \\
\hline SR (7) & 4.64 & 2.20 & .733 & - & - & - & - & - & - & 1 & $.393^{* *}$ & $.241^{* \star *}$ & $.264^{* *}$ & $.495^{* *}$ \\
\hline$S C(8)$ & 5.79 & 3.14 & .606 & - & - & - & - & - & - & - & 1 & $.332^{* \star \star}$ & $.267^{\star *}$ & $.431^{* *}$ \\
\hline AF (9) & 6.54 & 2.18 & .624 & - & - & - & - & - & - & - & - & 1 & $.394^{* *}$ & $.347^{* *}$ \\
\hline Chall. (10) & 7.18 & 2.12 & .651 & - & - & - & - & - & - & - & - & - & 1 & $.329^{* *}$ \\
\hline HE (11) & 4.48 & 1.88 & .652 & - & - & - & - & - & - & - & - & - & - & 1 \\
\hline
\end{tabular}

Note: $M=$ Mean; SD = Standard Deviation; $\alpha$ = Cronbach Alpha; Weight and body image = BWl; Fun and well-being = FWB; Prevention and positive health = PPH; Competition = Comp.; Affiliation = Affilia.; Strength and muscular endurance = EME Social recognition = SR; Agility and flexibility = AF; Stress control = SC; Challenge = Chall.; Health emergencies $=H E .{ }^{*}$ The correlation is significant at level .05 (Bilateral). ${ }^{* *}$ The correlation is significant at level .01 (Bilateral).

Table 2. Descriptive data of the analysed variables of AMPEF. Mean, Standard Deviation, regarding gender an age.

\begin{tabular}{|c|c|c|c|c|c|c|c|}
\hline \multirow[b]{2}{*}{ Dimension } & \multirow[b]{2}{*}{ Age } & \multicolumn{2}{|c|}{ Total $(n=163)$} & \multicolumn{2}{|c|}{ Boys $(n=80)$} & \multicolumn{2}{|c|}{ Girls ( $n=83$ ) } \\
\hline & & $M$ & $S D$ & $M$ & $S D$ & $M$ & $S D$ \\
\hline \multirow{3}{*}{ Weight and body image } & $10(n=56)$ & 5.72 & 1.68 & 5.56 & 1.62 & 5.82 & 1.73 \\
\hline & $11(n=71)$ & 5.12 & 2.13 & 5.84 & 1.99 & 4.28 & 2.00 \\
\hline & $12(n=36)$ & 5.76 & 2.10 & 6.13 & 2.38 & 5.23 & 1.56 \\
\hline & $10(n=56)$ & 6.99 & 1.79 & 7.05 & 1.75 & 6.96 & 1.83 \\
\hline \multirow[t]{3}{*}{ Fun and well-being } & $11(n=71)$ & 7.61 & 1.59 & 8.21 & 1.59 & 6.92 & 2.11 \\
\hline & $12(\mathrm{n}=36)$ & 7.14 & 2.22 & 7.27 & 2.40 & 6.96 & 2.00 \\
\hline & $10(n=56)$ & 7.59 & 1.62 & 7.57 & 1.69 & 7.61 & 1.61 \\
\hline \multirow[t]{3}{*}{ Prevention and positive health } & $11(n=71)$ & 7.79 & 2.12 & 8.01 & 1.82 & 7.54 & 2.43 \\
\hline & $12(n=36)$ & 7.41 & 1.96 & 7.74 & 2.11 & 6.96 & 1.69 \\
\hline & $10(n=56)$ & 6.03 & 1,88 & 6.30 & 1.94 & 5.86 & 1.85 \\
\hline \multirow[t]{2}{*}{ Competition } & $11(n=71)$ & 5.98 & 2.64 & 7.02 & 2.44 & 4.78 & 2.37 \\
\hline & $12(n=36)$ & 6.02 & 2.44 & 6.63 & 2.27 & 5.16 & 2.49 \\
\hline \multirow{2}{*}{ Affiliation } & $10(\mathrm{n}=56)$ & 6.66 & 2.01 & 6.71 & 2.03 & 6.63 & 2.03 \\
\hline & $11(n=71)$ & 6.83 & 2.09 & 6.98 & 2.15 & 6.67 & 2.05 \\
\hline
\end{tabular}




\begin{tabular}{|c|c|c|c|c|c|c|c|}
\hline & $12(n=36)$ & 6.95 & 1.88 & 7.20 & 1.88 & 6.61 & 1.90 \\
\hline & $10(n=56)$ & 6.15 & 1.79 & 6.35 & 1.91 & 6.02 & 1.72 \\
\hline \multirow[t]{3}{*}{ Strength and muscular endurance } & $11(n=71)$ & 6.45 & 2.19 & 7.17 & 2.20 & 5.62 & 1.88 \\
\hline & $12(n=36)$ & 6.68 & 2.38 & 7.34 & 2.50 & 5.76 & 1.90 \\
\hline & $10(n=56)$ & 4.99 & 1.98 & 4.96 & 2.02 & 5.01 & 1.98 \\
\hline \multirow[t]{3}{*}{ Social recognition } & $11(n=71)$ & 4.17 & 2.18 & 4.75 & 2.09 & 3.51 & 2.13 \\
\hline & $12(n=36)$ & 4.56 & 2.23 & 4.73 & 2.26 & 4.31 & 2.24 \\
\hline & $10(n=56)$ & 6.58 & 1.98 & 6.42 & 2.05 & 6.67 & 1.96 \\
\hline \multirow[t]{3}{*}{ Agility and flexibility } & $11(n=71)$ & 6.70 & 2.05 & 6.69 & 2.06 & 6.71 & 2.06 \\
\hline & $12(n=36)$ & 6.32 & 2.69 & 6.76 & 2.67 & 5.71 & 2.69 \\
\hline & $10(n=56)$ & 6.25 & 3.82 & 6.04 & 2.51 & 6.38 & 4.46 \\
\hline \multirow[t]{3}{*}{ Stress control } & $11(n=71)$ & 5.52 & 2.79 & 6.25 & 2.49 & 4.67 & 2.91 \\
\hline & $12(n=36)$ & 5.50 & 2.75 & 5.60 & 3.14 & 5.37 & 2.18 \\
\hline & $10(n=56)$ & 7.32 & 2.59 & 7.40 & 1.92 & 7.27 & 2.95 \\
\hline \multirow[t]{3}{*}{ Challenge } & $11(n=71)$ & 7.24 & 1.81 & 7.44 & 1.79 & 7.01 & 1.83 \\
\hline & $12(n=36)$ & 6.61 & 1.84 & 6.84 & 2.04 & 6.28 & 1.53 \\
\hline & $10(n=56)$ & 4.98 & 1.77 & 4.84 & 1.84 & 5.07 & 1.74 \\
\hline \multirow[t]{2}{*}{ Health emergencies } & $11(n=71)$ & 4.70 & 1.89 & 5.37 & 1.85 & 3.93 & 1.64 \\
\hline & $12(n=36)$ & 4.67 & 1.97 & 4.96 & 2.15 & 4.26 & 1.68 \\
\hline
\end{tabular}

Note: $M=$ Mean; $S D=$ Standard Deviation. 
Finally, regarding the health urgencies, the main significant effects of the gender factor were observed [F ( 1 , $157)=4.444, p=.037, \eta^{2}=.028$ ], there were higher punctuations among girls than boys. Significant effects of the age factor were not found $(p=.590)$ and neither regarding the interaction between them $[F(2,157)=$ $\left.3.190, p=.44, \eta^{2}=.039\right]$.

On the pair comparisons, were found significant statistic differences on the weight and body image factor ( $p$ $=.004)$, on the social recognition factor $(p=.012)$ and on the health urgencies factor $(p=.033)$ between 10 and 11 years old girls, because the values given by 10 years old girls were higher.

These comparisons also showed statistically significant differences regarding weight and body image $(p=$ $.001)$, entertainment and well-being $(p=.006)$, regarding the competition factor $(p<.001)$, muscular strength and endurance $(p=.002)$, social recognition $(p=.015)$, stress control $(p=.038)$ and also regarding health urgencies $(p=.001)$, between 11 years old boys and girls, because boys gave higher values than girls.

\section{DISCUSSION}

Even though the benefits that the regular practice of physical activity brings to the human being, there is a major decrease of it among teenagers (Roman, Serra-Majem, Ribas-Barba, Pérez-Rodrigo, \& Aranceta, 2008), as well as a dropout rate (Currie, Gabhainn, \& Godeau, 2008). Accordingly, it is necessary to know the existing motivation towards AF practice among the youth, in order to establish strategies focused on promoting the adherence to these practices, generating independent persons with healthier habits so the dropout rate can be decreased. That is why, the objective of this research was to determine the reasons why $5^{\circ}$ an $6^{\circ}$ Primary Education students practiced AF regarding their gender (boys. girls) and their age (10-12 years old), in four Galician schools by the AMPEF questionnaire.

The obtained results after the AMPEF questionnaire was collected regarding AF practice due to gender (boys-girls) among the $5^{\circ}$ and $6^{\circ}$ Primary Education students, it must be highlighted those boys are more concerned about weight and physical appearance, and so the reason why they practice sports is to control their weight and because of the desire to obtain a body they like better, unlike girls. Generally for high school students (Portela \& Domínguez, 2017) and also university students (Capdevila et al., 2007), this dimension is less important.

Regarding entertainment and well-being, high punctuations were registered with both boys and girls, which indicates that the purpose of the physical activity among these students is to feel better or to have a good time. The same results obtained regarding high school students (Portela \& Domínguez, 2017) and university students (Capdevila et al., 2007).

Most of the active, and also non active, girls and boys considered that prevention and health areas were not important reasons to carry out exercise in order to avoid diseases, unlike the research made by Portela \& Domínguez (2017) with high school students, by Capdevila et al. (2007) with university students, and also by Lobo (2009) with adults. This fact indicated that the society is not aware of the importance of practicing exercise daily to avoid chronic diseases. That is why it should be highlighted to the youth (t10 and 12 years old boys and girls) so they can develop healthier life habits.

Compared to other factors, competition got lower values, and the same happened regarding high school students (Portela \& Domínguez, 2017) and university students (Capdevila et al., 2007). However, boys give 
more importance than girls do, significantly. This may be due to family facts (parental pressure too much focused-on results) and/or social (masculine sportive figures).

Regarding muscular strength and endurance, the general punctuations were low, unlike what high school students (Portela \& Domínguez, 2017) and university students think (Capdevila et al., 2007), which indicates that for the youth is not important to keep or improve the muscular component when they carry out exercise.

For agility and flexibility generally, the results were slightly higher than those given by high school students (Portela \& Domínguez, 2017), but lower than those given by university students (Capdevila et al., 2007). There were not important differences between boys and girls in the current research.

The general results regarding social recognition were also low, and the same happened with high school students (Portela \& Domínguez, 2017) and university students (Capdevila Ortís et al., 2007). Also, there were not significant differences between Primary Education boys and girls, while those referring to social relations between students, of primary, high school and university were high (Capdevila et al., 2007; Portela \& Domínguez, 2017) which demonstrates that socialization is a very important factor to have fun with others while exercise is practised. In this case, differences between boys and girls from primary school are not significant.

The factor of health urgencies shows significant differences between boys and girls. Girls give the higher score on Primary Education, so girls have more motivation to practice sports because of health urgencies.

Regarding age, 10 years old girls consider more important the weigh factor and the body image, the social recognition and the healthy urgency as main motivations to practice physical exercise. This can be due to the current society stereotypes where image and body cult are factors that the youth has in mind all the time, especially because of the social media and the prescription of physical exercise to solve health problems girls of this age have (Navarro-Patón, Arufe-Giraldez, \& Martinez-Breijo, 2019).

When the motivation to make physical exercise is compared between boys and girls of 11 years old, boys obtain higher values regarding weight and body image, entertainment and well-being, competition, strength and muscular resistance, social recognition, stress control and health emergencies, which indicates that boys have more predisposition than girls of their same age to practice physical activity. Similar results to the ones obtained by Navarro-Patón, Pazos-Couto, Rodríguez-Fernández and Arufe-Giraldez (2019).

\section{CONCLUSIONS}

$5^{\circ}$ and $6^{\circ}$ Primary Education students show more motivation than girls towards physical activity, influenced by weight, body image, competition, muscular strength and resistance and the health urgencies.

10 years old girls show more motivation towards physical activity than 11- and 12-years old girls regarding weight and body image, social recognition and health urgencies.

11 years old boys show more motivation towards physical activity than girls of the same age regarding weight, corporal image, entertainment and well-being, competition, strength and muscular resistance, social recognition, stress control and health urgencies. 


\section{AUTHOR CONTRIBUTIONS}

All authors have participated in all parts of the research work and in the preparation of the article (Conception and design of the study, acquisition, analysis and interpretation of the data, revision of the content, and final approval of this document).

\section{SUPPORTING AGENCIES}

No funding agencies were reported by the authors.

\section{DISCLOSURE STATEMENT}

The authors declare no conflicts of interest.

\section{REFERENCES}

Alba-Martín, R. (2016). Prevalence of childhood obesity \& eating habits in primary education. Enfermeria Global, 15(2), 40-62. https://doi.org/10.6018/eglobal.15.2.212531

Aranceta-Bartrina, J., \& Pérez-Rodrigo, C. (2018). Childhood Obesity: An Unresolved Issue. Revista Espanola de Cardiologia, 71(11), 888-891. https://doi.org/10.1016/j.recesp.2018.04.038

Barbeira, S., Navarro, R., \& Rodriguez, J.E. (2017). Hábitos deportivos y de actividad física en escolares de educación primaria en función de la edad y el género. Orientaciones desde del área de didáctica de la educación física. EmásF, Revista Digital de Educación Física, 44, 94-111.

Campo-Ternera, L., Herazo-Beltrán, Y., García-Puello, F., Suarez-Villa, M., Méndez, O., \& Vásquez-De La Hoz, F. (2017). Healthy lifestyles of children and adolescents. Barranquilla (Col.) (Vol. 33). https://doi.org/10.14482/sun.33.3.10931

Capdevila, L., Niñerola, J., \& Pintanel, M. (2004). Motivación y actividad física: el autoinforme de motivos para la práctica de ejercicio físico (AMPEF). Revista de Psicología Del Deporte, 13(1), 55-74.

Capdevila Ortís, L., Niñerola Maymí, J., Cruz Feliu, J., Losilla Vidal, J. M., Parrado Romero, E., Pintanel Bassets, M., ... Vives Brosa, J. (2007). Exercise motivation in university community members: A behavioural intervention. Psicothema, 19(2), 250-255.

Currie, C., Gabhainn, S., \& Godeau, E. (2008). Inequalities in young people's health. Health behaviour in school-aged children. International report from the 2005/2006 survey. Health Policy for Children and Adolescents, 5, 105-112.

de Greeff, J. W., Bosker, R. J., Oosterlaan, J., Visscher, C., \& Hartman, E. (2018, May 1). Effects of physical activity on executive functions, attention and academic performance in preadolescent children: a meta-analysis. Journal of Science and Medicine in Sport. Elsevier Ltd. https://doi.org/10.1016/i.jsams.2017.09.595

Deci, E. L., \& Ryan, R. M. (1985). Intrinsic motivation and self-determination in human behavior. Plenum.

Donnelly, J. E., Hillman, C. H., Castelli, D., Etnier, J. L., Lee, S., Tomporowski, P., ... Szabo-Reed, A. N. (2016, June 1). Physical activity, fitness, cognitive function, and academic achievement in children: A systematic review. Medicine and Science in Sports and Exercise. Lippincott Williams and Wilkins. https://doi.org/10.1249/MSS.0000000000000901

Grosso, G., \& Galvano, F. (2016, August 1). Mediterranean diet adherence in children and adolescents in southern European countries. NFS Journal. Elsevier $\mathrm{GmbH}$. https://doi.org/10.1016/j.nfs.2016.02.004 
Ley Orgánica 8/2013, de 9 de diciembre, para la mejora de la calidad educativa. (n.d.). Boletín Oficial Del Estado, 295, 97858-97921.

Lobo, A. (2009). Motivation para la actividad fisica e su relation con la qalidad de vida. Revista Brasileira de Geriatria e Gerontologia, 12(3), 405-415. https://doi.org/10.1590/1809-9823.2009.00008

López-Castaño, E. M., Navarro-Patón, R., \& Basanta-Camiño, S. (2015). ¿Qué tipo de motivación predomina en los escolares de educación primaria hacia la educación física? Un estudio descriptivo. EmásF: Revista Digital de Educación Física, 35, 152-160.

Marques, A., Gómez, F., Martins, J., Catunda, R., \& Sarmento, H. (2016). Association between physical education, school-based physical activity, and academic performance: a systematic review (Asociación entre la educación física, la actividad física en la escuela, y el rendimiento académico: una revisión sistemática). Retos, 0(31), 316-320. Retrieved from https://recyt.fecyt.es/index.php/retos/article/view/53509

Martínez-Vizcaíno, V., Sánchez-López, M., Salcedo-Aguilar, F., Notario-Pacheco, B., Solera-Martínez, M., Moya-Martínez, P., ... Rodríguez-Artalejo, F. (2012). Protocolo de un ensayo aleatorizado de clusters para evaluar la efectividad del programa MOVI-2 en la prevención del sobrepeso en escolares. Revista Espanola de Cardiologia, 65(5), 427-433. https://doi.org/10.1016/j.recesp.2011.12.008

Moreno, J. A., \& Martínez, A. (2006). Importancia de la teoría de la autodeterminación en la práctica físico-deportiva: Fundamentos e implicaciones prácticas. Cuadernos de Psicología Del Deporte, $6(2)$.

Muñoz-Heras, A., Fernández-Pedraza, N., \& Navarro-Patón, R. (2015). Estudio descriptivo sobre los hábitos saludables en alumnado de Primaria desde la educación física escolar. Sportis. Scientific Journal of School Sport, Physical Education and Psychomotricity, 1(1), 87. https://doi.org/10.17979/sportis.2015.1.1.1402

Navarro-Patón, R.; Arufe Giraldez, V.; Martinez-Breijo, J. (2019). Estudio descriptivo. Sobre estereotipos de género asociados a la actividad física, deporte y educación física en escolares gallegos de educación primaria y secundaria. Journal of Sport and Health Research, in Press.

Navarro-Patón, R., Lago-Ballesteros, J., Basanta-Camiño, S., \& Arufe-Giraldez, V. (2019). Relation between motivation and enjoyment in physical education classes in children from 10 to 12 years old. Journal of Human Sport and Exercise, 14(3), 527-537. https://doi.org/10.14198/jhse.2019.143.04

Navarro-Patón, R., Pazos-Couto, J., Rodríguez-Fernández, J., \& Arufe-Giraldez, V. (2020). Measuring physical self-concept of schoolchildren aged 10 to 16 on physical education lessons. Journal of Human Sport and Exercise, 15(1), 1-13. https://doi.org/10.14198/jhse.2020.151.01

Organización Mundial de la Salud. (2017). Datos y cifras sobre obesidad infantil. WHO. World Health Organization. Retrieved from https://www.who.int/end-childhood-obesity/facts/es/

Pino-Juste, M., Portela-Pino, I., \& Abalde-Amoedo, N. (2016). Level of Physical Activity and Academic Performance. The International Journal of Pedagogy and Curriculum, 23, 53-65. https://doi.org/10.18848/2327-7963/CGP/v23i03/53-65

Portela Pino, I., \& Domínguez Alonso, J. (2017). Motivación percibida por los adolescentes gallegos en la práctica del ejercicio. Revista de Estudios e Investigación En Psicología y Educación, (14), 117. https://doi.org/10.17979/reipe.2017.0.14.2518

Pumar Vidal, B.; Navarro Patón, R.; Basanta Camiño, S. (2015). Efectos de un programa de actividad física en escolares. Educación Física y Ciencia, 17 (2), 1-13. En Memoria Académica.

Ríos, Y., Navarro, R., Arufe, V., \& Pérez, J. A. (2018). Evaluación de un programa de actividad física mediante juegos populares en escolares de Educación Primaria. Retos: nuevas tendencias en educación física, deporte y recreación, 34, 108-113. 
Roman, B., Serra-Majem, L., Ribas-Barba, L., Pérez-Rodrigo, C., \& Aranceta, J. (2008). How many children and adolescents in Spain comply with the recommendations on physical activity? Journal of Sports Medicine and Physical Fitness, 48(3), 380-387.

Sabo, D., \& Veliz, P. (2016). Inequalities in Athletic Participation During Adolescence: A Nationwide Study of Attrition Rates in Organized Sports in the United States. Health Behavior and Policy Review, 3, 88-98. https://doi.org/10.14485/HBPR.3.2.1

Salas-Cabrera, J. (2016). Estilos de vida saludables: un derecho fundamental en la vida del ser humano. Revista Latinoamericana de Derechos Humanos, 26(2), 37. https://doi.org/10.15359/rldh.26-2.2 